\title{
THE WATER FOOTPRINT OF
}

SOY MILK AND SOY BURGER AND

\section{EQUIVALENT ANIMAL PRODUCTS}

FEBRUARY 2011 



\title{
THE WATER FOOTPRINT OF SOY MILK AND SOY BURGER AND EQUIVALENT ANIMAL PRODUCTS
}

\author{
A.E. ERCIN ${ }^{1}$ \\ M.M. ALDAYA ${ }^{2}$ \\ A.Y. HOEKSTRA ${ }^{1}$
}

FEBRUARY 2011

Value of Water Research Report Series No. 49 ${ }^{1}$ Twente Water Centre, University of Twente, Enschede, The Netherlands;
corresponding author: Arjen Hoekstra, e-mail a.y.hoekstra@utwente.nl

\footnotetext{
${ }^{2}$ United Nations Environment Programme, Division of Technology, Industry and Economics, Sustainable Consumption and Production Branch, Paris, France
} 
(C) 2011 A.E. Ercin, M.M. Aldaya and A.Y. Hoekstra.

Published by:

UNESCO-IHE Institute for Water Education

P.O. Box 3015

2601 DA Delft

The Netherlands

The Value of Water Research Report Series is published by UNESCO-IHE Institute for Water Education, in collaboration with University of Twente, Enschede, and Delft University of Technology, Delft.

All rights reserved. No part of this publication may be reproduced, stored in a retrieval system, or transmitted, in any form or by any means, electronic, mechanical, photocopying, recording or otherwise, without the prior permission of the authors. Printing the electronic version for personal use is allowed.

Please cite this publication as follows:

Ercin, A.E., Aldaya, M.M and Hoekstra, A.Y. (2011) The water footprint of soy milk and soy burger and equivalent animal products, Value of Water Research Report Series No. 49, UNESCO-IHE, Delft, the Netherlands. 


\section{Contents}

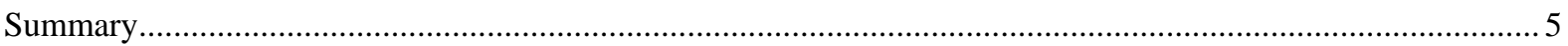

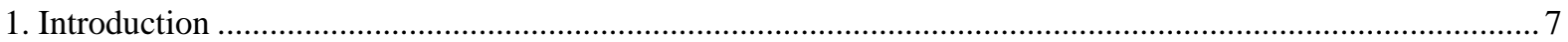

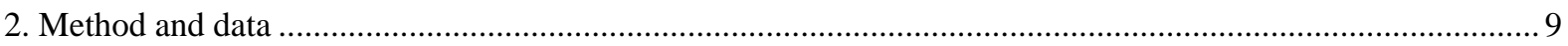

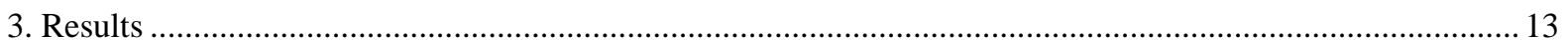

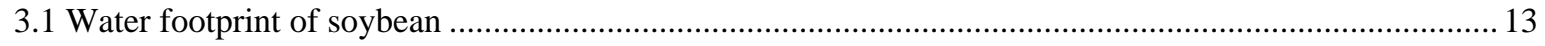

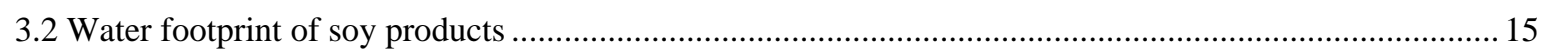

3.3 Water footprint of soy products versus equivalent animal products ..................................................... 19

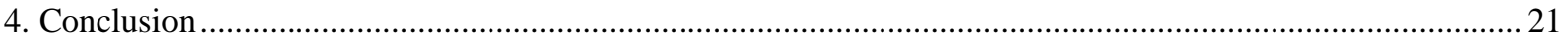

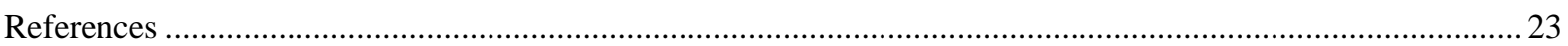

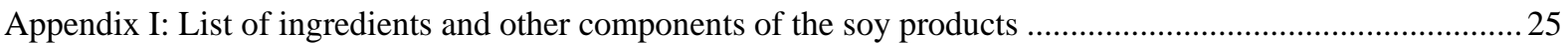

Appendix II: Water footprints of raw materials and process water footprints for the ingredients and other components of the soy products.....

Appendix III: Fertilizer and pesticide application and the grey water footprint related to soybean production in the analysed farms in Canada, China and France. 



\section{Summary}

As all human water use is ultimately linked to final consumption, it is interesting to know the specific water consumption and pollution behind various consumer goods, particularly for goods that are water-intensive, such as foodstuffs. This information is relevant, not only for consumers, but also for food producers and processors, retailers, traders and other businesses that play a role in supplying those goods to the consumers.

The objective of this study is to quantify the water footprints of soy milk and soy burger and compare them with the water footprints of equivalent animal products (cow's milk and beef burger). The study focuses on the assessment of the water footprint of soy milk produced in a specific factory in Belgium and soy burger produced in another factory in the Netherlands. The ingredients and sources of these ingredients are taken according to real case studies. We analysed organic and non-organic soybean farms in three different countries from where the soybeans are imported (Canada, China, and France). Organic production, which relies on animal manure, compost, biological pest control, and mechanical cultivation to maintain soil productivity and control pests, excluding or strictly limiting the use of synthetic fertilizers and pesticides, reduces soil evaporation and diminishes the grey water footprint, ultimately reducing the total water footprint.

The water footprint of 1 litre soy milk produced in Belgium amounts to 297 litres, of which 99.7\% refers to the supply chain. The water footprint of a $150 \mathrm{~g}$ soy burger produced in the Netherlands is 158 litres, of which 99.9\% refers to the supply chain. Although most companies focus on just their own operational performance, this study shows that it is important to consider the complete supply chain. The major part of the total water footprint stems from ingredients that are based on agricultural products. In the case of soy milk, $62 \%$ of the total water footprint is due to the soybean content in the product; in the case of soy burger, this is 74\%. Thus, a detailed assessment of soybean cultivation is essential to understand the claim that each product makes on freshwater resources. This study shows that shifting from non-organic to organic farming can reduce the grey water footprint related to soybean cultivation by $98 \%$.

Cow's milk and beef burger have much larger water footprints than their soy equivalents. The global average water footprint of a 150 gram beef burger is 2350 litres and the water footprint of 1 litre of cow's milk is 1050 litres. These figures include the water footprint of packaging, but this component contributes no more than a few per cent to the total. 



\section{Introduction}

Given that severe freshwater scarcity is a common phenomenon in many regions of the world, improving the governance of the world's limited annual freshwater supply is a major challenge, not only relevant to water users and managers but also to final consumers, businesses and policymakers in a more general sense (UNESCO, 2006). About 86\% of all water used in the world is to grow food (Hoekstra and Chapagain, 2008). Therefore, food choices can have a big impact on water demand (Steinfeld et al., 2006; De Fraiture et al., 2007; Peden et al., 2007; Galloway et al., 2007). In industrialised countries, an average meat-eater consumes the equivalent of about 3600 litres of water a day, which is 1.6 times more than the 2300 litres used daily by people on vegetarian diets (assuming the vegetarians still consume dairy products; Hoekstra, 2010).

Freshwater is a basic ingredient in the operations and supply chains of many companies. A company may face various sorts of risk related to failure to manage freshwater supplies: damage to its corporate image, the threat of increased regulatory control, financial risks caused by pollution, and inadequate freshwater availability for business operations (Rondinelli and Berry, 2000; Pegram et al., 2009). The need for the food industry to take a responsible approach towards the sustainable use and conservation of freshwater is therefore vital.

The 'water footprint' is an indicator of water use that looks at both direct and indirect water use by a consumer or producer (Hoekstra, 2003). The water footprint is a comprehensive indicator of freshwater resources appropriation, beyond the traditional but rather restrictive measure of water withdrawal. The water footprint of a product is the volume of freshwater used to produce the product, measured over the full supply chain. It is a multi-dimensional indicator, showing water consumption volumes by source and polluted volumes by type of pollution; all components of the water footprint are specified both geographically and temporally (Hoekstra et al., 2011). The blue water footprint refers to consumption of blue water resources (surface and ground water) along the supply chain of a product. 'Consumption' refers to the loss of water from the available ground and surface water in a given catchment area, which happens when water evaporates, has been incorporated into a product or returns to another catchment area or the sea. The green water footprint refers to consumption of green water resources (rainwater). The grey water footprint refers to pollution and is defined as the volume of freshwater that is required to assimilate the load of pollutants based on existing ambient water quality standards.

This paper analyses the water footprints of soy milk and soy burger and compares them with the water footprints of the two equivalent animal products (cow's milk and beef burger). For this purpose, the study identifies the production-chain diagram for 1 litre of soy milk and a $150 \mathrm{~g}$ soy burger, indicating the relevant process steps from source to final product and identifying the steps with a substantial water footprint. The study focuses on the assessment of the water footprint of soy milk produced in a specific factory in Belgium and soy burger produced in a specific factory in the Netherlands. The soybeans used in the manufacturing of the soy products in these two countries are imported. The study starts with the assessment of the water footprint of soybean cultivation in Canada, China and France, three of the actual source countries, differentiating between the green, blue and grey water footprint components. Different types of soybean production systems are analysed: organic versus non-organic and irrigated versus rainfed. Next, the water footprint of each of the final products is 
8 / The water footprint of soy milk and soy burger and equivalent animal products

assessed based on the composition of the product and the characteristics of the production process and producing facility. Finally, we compare the water footprints of soy products with the water footprints of equivalent animal products. 


\section{Method and data}

We estimate the water footprint of 1 litre of soy milk produced in Belgium and the water footprint of a $150 \mathrm{~g}$ soy burger produced in the Netherlands. We consider five different soybean sources: (1) Canadian rainfed organic soybean; (2) Canadian rainfed non-organic soybean; (3) Chinese rainfed organic soybean; (4) French rainfed non-organic soybean; (5) French irrigated non-organic soybean.

The water footprints of different ingredients and other inputs are calculated distinguishing between the green, blue and grey water footprint components. The water footprint definitions and calculation methods applied follow the global standard as provided in Hoekstra et al. (2011).

Taking the perspective of the producer of the soy milk and soy burger, the water footprints of the soy products include an operational and a supply-chain water footprint. The operational (or direct) water footprint is the volume of freshwater consumed or polluted in the operations of the producer of the soy products. It refers to the freshwater appropriated during the production of the soy products from their basic ingredients: water incorporated into the products, water evaporated during production processes and the volume of water polluted because of wastewater leaving the factory. The supply-chain (or indirect) water footprint is the volume of freshwater consumed or polluted to produce all the goods and services that form the input of production of the business. Both operational and supply-chain water footprints consist of two parts: the water footprint that can be directly related to inputs applied in or for the production of our product and an overhead water footprint. The overhead components of the operational and supply-chain water footprints are excluded from this study as they are negligible compared to the total water footprint for food-based products (Ercin et al., 2011).

Figures 1 and 2 show the production system of soy milk and soy burger, respectively. These production diagrams show the major process steps during the production and the inputs for each step that are most relevant for water footprint accounting.

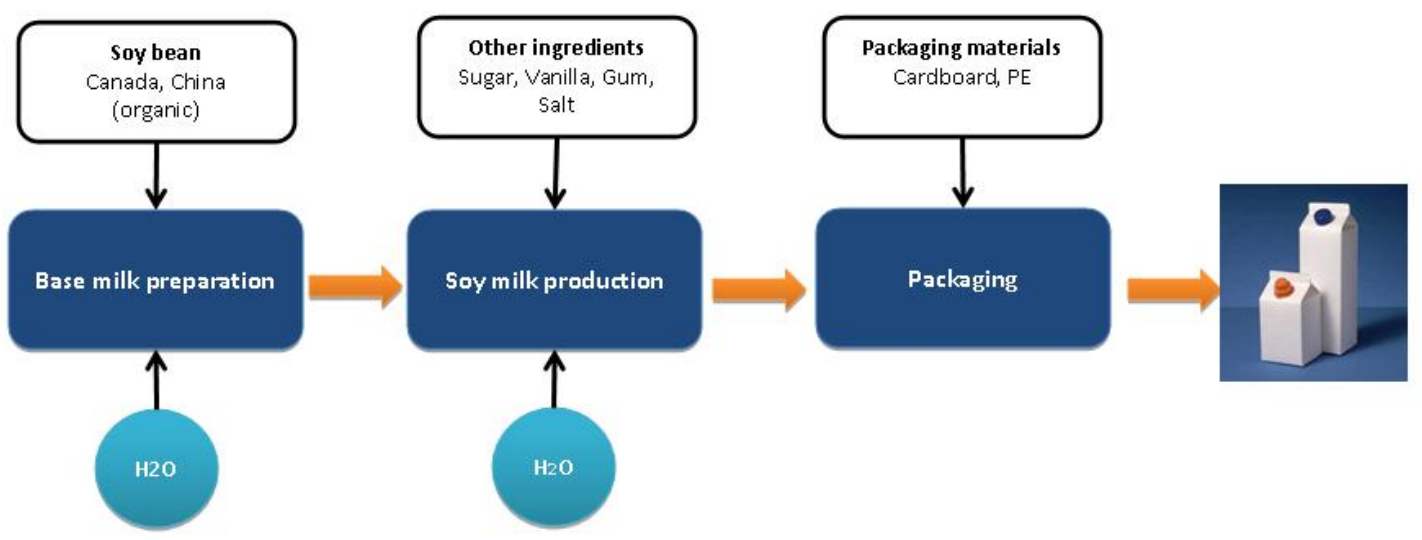

Figure 1. Production-chain diagram of soy milk produced in Belgium. 


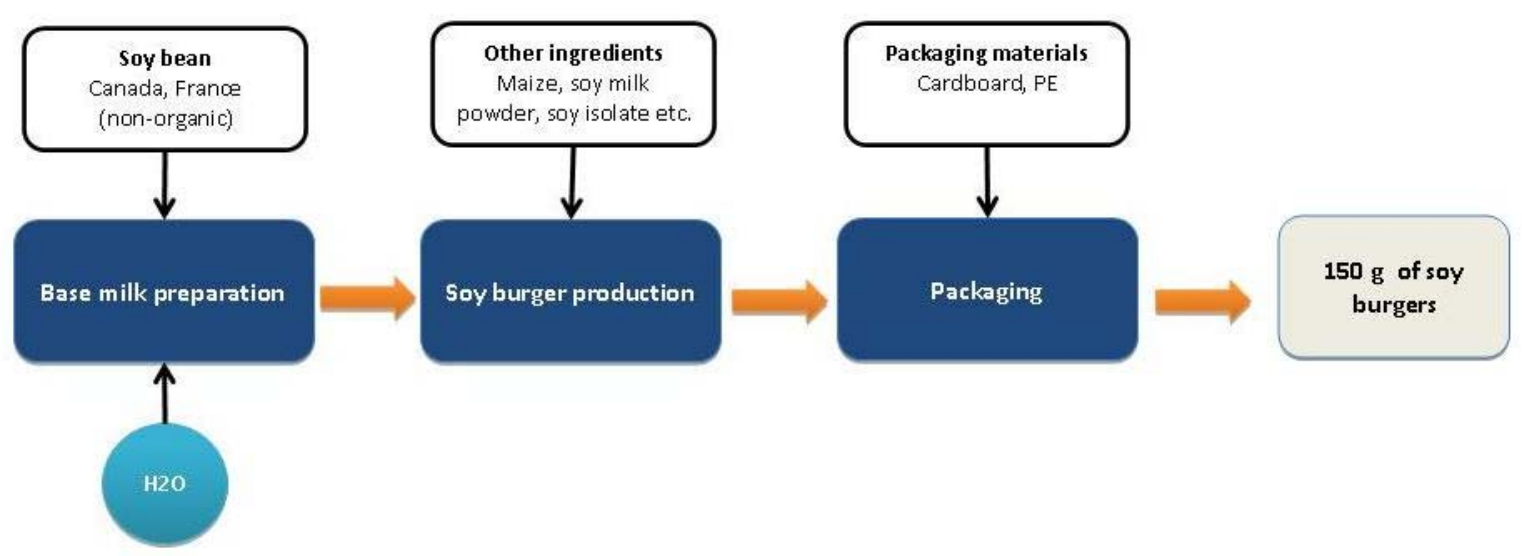

Figure 2. Production-chain diagram of a $150 \mathrm{~g}$ soy burger produced in the Netherlands.

The data related to the operational water footprint of soy milk and soy burger are taken from two real factories in Belgium and the Netherlands. Both factories have treatment plants that treat the wastewater before discharging it into the receiving water bodies. We took the grey water footprint as zero by assuming that the concentration of the pollutant in the effluent is equal to its actual concentration in the receiving water body.

The water used as an ingredient is equal to 0.1 litres per $150 \mathrm{~g}$ of soy burger and 0.9 litres per 1 litre of soy milk. The production of soy milk and soy burger includes the following process steps: base milk preparation, mixing, filling, labelling and packaging. During all these processes, the amount of water lost (evaporated) is zero.

The supply-chain water footprint is composed of the water footprints of ingredients (e.g. basemilk, sugar, maize, and natural flavouring in the case of soy milk) and the water footprints of other components (e.g. bottle, cap, labelling materials, packaging materials). The list of ingredients and amounts used in the soy products are taken from real case studies. Appendix I shows the data used. For the soy milk, the soybean is supplied from two different farms that cultivate organic soybean: a rainfed farm located in China and a rainfed farm located in Canada. In the production stage of the soy milk, a mix of soybean from these two farms is used, according to a ratio of 50 to 50. For the soy burger, soybean is supplied from three non-organic farms: a rainfed farm located in Canada, a rainfed farm located in France, and an irrigated farm in the same region in France. A mix of soybeans from these farms is used in the soy burger, according to a ratio of 50/25/25.

The water footprints of the different soybeans have been calculated as will be described below. For the other agricultural ingredients, water footprints of raw products, product fractions and value fractions have been taken from Mekonnen and Hoekstra (2010a). We calculated the product and value fractions of the vanilla extract by referring the extracting process defined as in FDA (2006). In this calculation, we assumed that single fold vanilla extract is used in the soy milk. The water footprints of the raw materials, process water footprints, product fractions and value fractions that are the basis for the water footprint calculations of soy milk and soy burger are given in Appendix II. 
The green, blue and grey water footprints of soybean grown in Canada, China and France were calculated using the methodology described in Hoekstra et al. (2011). The green and blue water evapotranspiration were estimated using the CROPWAT model (Allen et al., 1998; FAO, 2009a). Within the CROPWAT model, the 'irrigation schedule option' was applied, which includes a dynamic soil water balance and tracks the soil moisture content over time (Allen et al., 1998). The calculations were done using climate data from the nearest and most representative meteorological stations and a specific cropping pattern for each crop according to the type of climate (Table 1). Monthly values of major climatic parameters were obtained from the CLIMWAT database (FAO, 2009b). Crop area data were taken from Monfreda et al. (2008); crop parameters were taken from Allen et al. (1998) and FAO (2009a). Types of soil and average crop yield data were obtained from the farms (Table 1). Soil information was taken from FAO (2009a).

Table 1. Planting and harvesting dates, yield and type of soil for the five soybean farms considered.

\begin{tabular}{lcccc}
\hline Crop & Planting date * & Harvesting date * & Yield (ton/ha) * & Type of soil \\
\hline Canada organic rainfed & 15 May & 11 October & 2.4 & Sandy loam - Clay loam \\
Canada non-organic rainfed & 15 May & 11 October & 2.5 & Clay loam \\
China organic rainfed & 15 May & 11 October & 2.9 & Brown soil \\
France non-organic rainfed & 15 May & 11 October & 1.9 & Calcareous clay \\
France non-organic irrigated & 15 May & 11 October & 3.1 & Calcareous clay \\
\hline
\end{tabular}

* Farm data

In the case of the Chinese organic soybean production, organic compost mixed with the straw of the crop and the waste of livestock was applied. $50 \%$ of the soil surface was assumed to be covered by the organic crop residue mulch, with the soil evaporation being reduced by about 25\% (Allen et al., 1998). For the crop coefficients in the different growth stages this means: $\mathrm{K}_{\mathrm{c}, \text { ini, }}$, which represents mostly evaporation from soil, is reduced by about $25 \%$; $\mathrm{K}_{\mathrm{c} \text {,mid }}$ is reduced by $25 \%$ of the difference between the single crop coefficient $\left(\mathrm{K}_{\mathrm{c} \text {,mid }}\right)$ and the basal crop coefficient $\left(\mathrm{K}_{\mathrm{cb} \text {,mid }}\right)$; and $\mathrm{K}_{\mathrm{c} \text {,end }}$ is similarly reduced by $25 \%$ of the difference between the single crop coefficient $\left(\mathrm{K}_{\mathrm{c} \text {,end }}\right)$ and the basal crop coefficient $\left(\mathrm{K}_{\mathrm{cb} \text {,end }}\right)$. Generally, the differences between the $\mathrm{K}_{\mathrm{c}}$ and $K_{c b}$ values are only 5-10\%, so that the adjustment to $K_{c \text {,mid }}$ and $K_{c, \text { end }}$ to account for organic mulch may not be very large.

Generally, soybean production leads to more than one form of pollution. The grey water footprint was estimated separately for each pollutant and finally determined by the pollutant that appeared to be most critical, i.e. the one that is associated with the largest pollutant-specific grey water footprint (if there is enough water to assimilate this pollutant, all other pollutants have been assimilated as well). The total volume of water required per ton of pollutant was calculated by considering the volume of pollutant leached (ton/ton) and the maximum allowable concentration in the ambient water system. The natural concentration of pollutants in the receiving water body was assumed to be negligible. Pollutant-specific leaching fractions and ambient water quality standards were taken from the literature (Appendix III). In the case of phosphorus, good estimates on the fractions that reach the water bodies by leaching or runoff are very difficult to obtain. The problem for a substance like phosphorus (P) 
is that it partly accumulates in the soil, so that not all $\mathrm{P}$ that is not taken up by the plant immediately reaches the groundwater, but on the other hand may do so later. In this study we assumed a P leaching rate of zero.

The supply-chain water footprint of soy products is not only caused by ingredients but also other components integral to the whole product. These include closure, labelling and packaging materials. The process water footprints and the water footprints associated with other raw materials used (oil, PE, LDPE, PP) have been derived from Van der Leeden et al. (1990). The detailed list of other components of the supply-chain water footprint of the product is given in Appendix I. The water footprints of raw materials, process water footprints, product fractions and value fraction are presented in Appendix II.

The water footprints of cow's milk and beef depend on the water footprints of the feed ingredients consumed by the animal during its lifetime and the water footprints related to drinking and service water (Hoekstra and Chapagain, 2008). Clearly, one needs to know the age of the animal when slaughtered and the diet of the animal during the various stages of its life. The water footprints of cow's milk and beef burger have been taken from Mekonnen and Hoekstra (2010b). For the comparison with the soy products, the water footprint of packaging is included in the water footprints of cow's milk and beef burger as well. 


\section{Results}

\subsection{Water footprint of soybean}

The water footprints of soybean cultivated in five different farms located in three different countries are shown in Figure 3. The soybean from the Canadian non-organic farm has the largest water footprint, followed by the two French non-organic farms, the Canadian organic farm and Chinese organic farm. The blue water footprint component is zero except for the soybean from the French irrigated farm. The soybean from the rest of the farms is rainfed. The largest grey water footprint is found for the soybean from the Canadian non-organic farm.

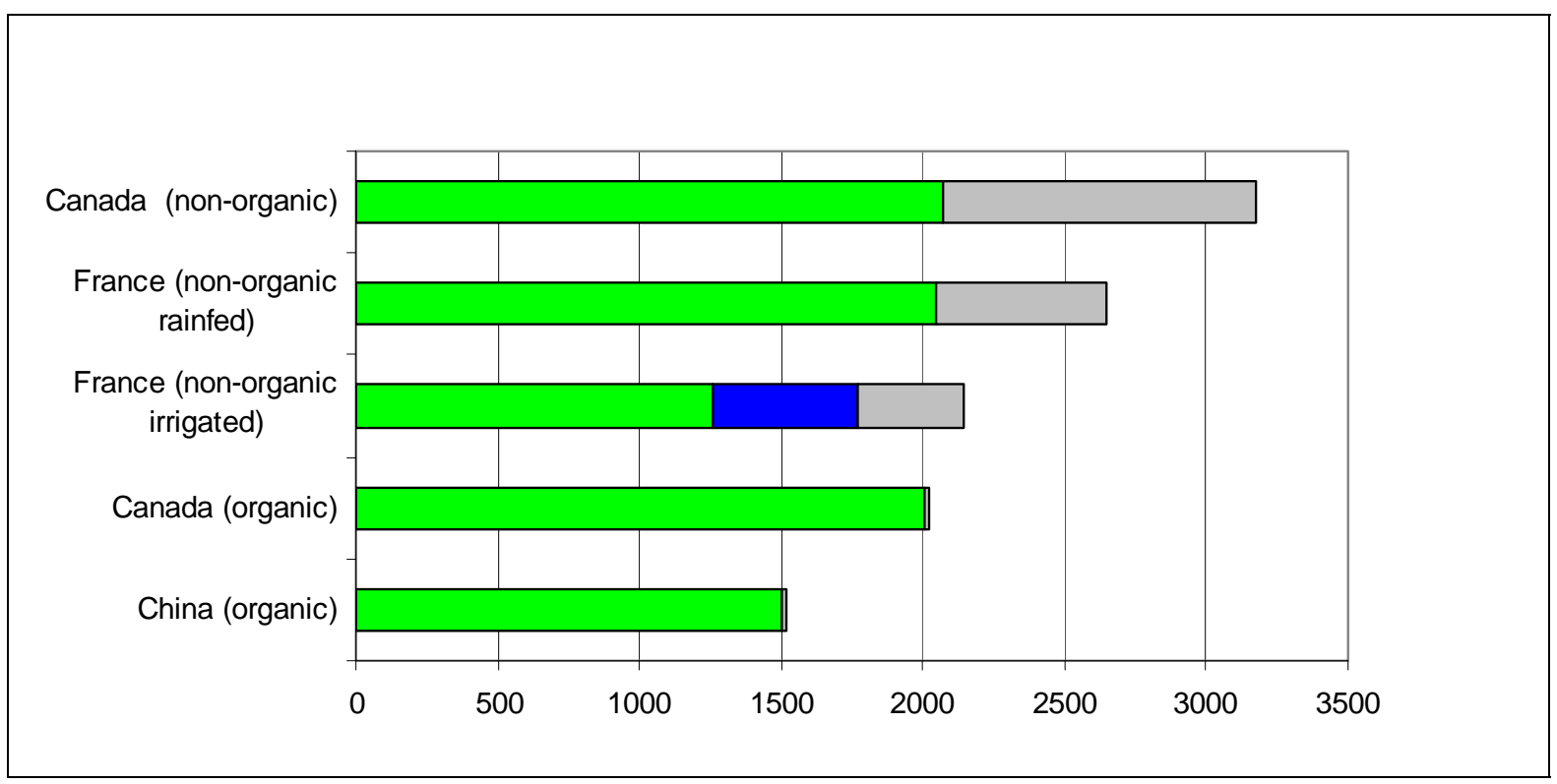

Figure 3. The water footprint of soybeans (as primary crops) from different farms ( $m^{3 / t o n)}$.

\subsubsection{Soybean cultivation in Canada}

In Canada, two different plantations were analysed: a rainfed organic and a rainfed non-organic soybean farm. Organic farmers grow crops without using synthetic pesticides or fertilizers, relying instead on a wide range of cultural practices and alternative inputs believed to be safer for the environment and the consumer. Soybeans are relatively easy to produce using organic methods. However, it is important to recognize that organic farms rarely focus on a single crop. Organic soybean is grown in rotation with several other crops that (ideally) complement or compensate for one another. Crop rotations serve two primary purposes: to improve soil fertility and to break pest cycles. With regard to fertility management, rotation strategies concentrate mainly on generating and conserving nitrogen. Nitrogen is commonly the most limiting element in organic production, especially for corn and small grains, which complement soybeans in most crop sequences. Crop rotations that include forage legumes are the key where nitrogen is supplied to the system (NCAT, 2004).

Crop yields for the organic and non-organic soybean production in the Canadian farms are similar (2.4 and 2.5 ton/ha, respectively). The water footprint of non-organic soybean production is about $3172 \mathrm{~m}^{3} /$ ton $\left(2069 \mathrm{~m}^{3} /\right.$ ton 
green and $1103 \mathrm{~m}^{3} /$ ton grey). The grey water footprint is determined by Boundary herbicide, which has the largest pollutant-specific grey water footprint $\left(1103 \mathrm{~m}^{3} /\right.$ ton $)$, followed by potassium chloride $\left(8 \mathrm{~m}^{3} / \mathrm{ton}\right)$, Touchdown $\left(1 \mathrm{~m}^{3} /\right.$ ton $)$ and TSP $\left(0 \mathrm{~m}^{3} /\right.$ ton $)$. Organic production has slightly lower water consumption because the evapotranspiration from the field is less (Allen et al., 1998) and results in much less pollution because the load of chemicals to groundwater and surface water is less. The total water footprint of organic soybean production in the Canadian farm is around $2024 \mathrm{~m}^{3} /$ ton (2004 $\mathrm{m}^{3} /$ ton green, $20 \mathrm{~m}^{3} /$ ton grey). In this case, the sulphate of potash is the most critical pollutant $\left(20 \mathrm{~m}^{3} /\right.$ ton). The nitrogen fertilization through symbiotic and endophytic bacteria as applied in organic farming has a zero grey water footprint.

\subsubsection{Soybean cultivation in China}

The Chinese organic rainfed farm under study achieves high yields, amounting to about 2.9 ton/ha, notably higher than the Chinese national average (1.7 ton/ha). The total water footprint of the Chinese organic rainfed soybean production is $1520 \mathrm{~m}^{3} /$ ton ( $1503 \mathrm{~m}^{3} /$ ton green and $17 \mathrm{~m}^{3} /$ ton grey) . The grey water footprint is related to the sulphate pollution coming from the sulphate of potash applied (Appendix III). The grey water footprint of nitrogen due to organic compost is $4 \mathrm{~m}^{3} /$ ton and the one of phosphorus $\left(\mathrm{P}_{2} \mathrm{O}_{5}\right)$ is negligible. In this case, organic compost mixed by the straw of the crop and the waste of the livestock is applied, mainly before planting. Mulching is a practice often used by organic growers. Traditionally, it entails the spreading of large amounts of organic materials — straw, old hay, wood chips, etc. — over otherwise bare soil between and among crop plants (Allen et al., 1998). Organic mulches regulate soil moisture and temperature, suppress weeds, and provide organic matter to the soil (NCAT, 2004). Mulches are frequently used in vegetable production to reduce evaporation losses from the soil surface, to accelerate crop development in cool climates by increasing soil temperature, to reduce erosion, or to assist in weed control. Composting and using livestock manure is a way of improving soil fertility. Animal wastes contain major nutrients and organic matter. Proper application and soil incorporation of fresh manure ensures the maximum capture and delivery of nitrogen to the crop. That is why manure is often applied prior to planting. There are several important considerations in the use of fresh manure. Composting is a means of stabilizing and enhancing livestock wastes for storage, in order to avoid certain problems inherent in applying fresh manure. Composts, though lower in total nitrogen, are fertilizers that are more balanced and more useful in building soil fertility over time (NCAT, 2004). Organic farming systems, therefore, help to maintain water quality by reducing the amount of chemicals used in agriculture, which can eventually find their way into lakes, rivers, streams and other bodies of water. In this way, organic farming reduces the risk of eutrophication of ground and surface water bodies - where excessive algae growth due to the abundance of nutrients reduces the oxygen content and threatens the health of the original ecosystems. In addition, organic farming practices such as a multi-annual crop rotation, appropriate plant selection and organic manure use, are supposed to improve soil structure and increase the soil's water retention capacity, thus reducing the need for crop irrigation in drier areas (EC, 2010). 


\subsubsection{Soybean cultivation in France}

The non-organic rainfed French farm studied has a low yield of around 1.9 ton/ha, whereas the irrigated one gives 3.1 ton/ha, higher than the national average (2.5 ton/ha). The water footprint of the soybean from the rainfed farm is calculated as $2651 \mathrm{~m}^{3} /$ ton $\left(2048 \mathrm{~m}^{3} /\right.$ ton green and $603 \mathrm{~m}^{3} /$ ton grey). The water footprint for the irrigated farm is estimated as $2145 \mathrm{~m}^{3} /$ ton $\left(1255 \mathrm{~m}^{3} /\right.$ ton green, $519 \mathrm{~m}^{3} /$ ton blue and $370 \mathrm{~m}^{3} /$ ton grey). In both cases, the grey water footprint is determined by the Lasso pesticide (alachlor) applied (603 and $370 \mathrm{~m}^{3} /$ ton for for rainfed and irrigated production, respectively), followed by the potassium chloride pollution (10 and 6 $\mathrm{m}^{3}$ /ton respectively) and TSP ( $\left.0 \mathrm{~m}^{3} / \mathrm{ton}\right)$. In this example, there is space for improving rainfed soybean yields and therefore reducing the water footprint. This could be done in number of ways, for example by selecting high-yielding, well-adapted varieties, controlling weeds prior to planting, planting at the optimum seeding rates, depth and timing, harvesting at the optimum stage and adjusting combine settings (Staton et al., 2010). The grey water footprint could also be reduced by shifting to integrated or organic farming systems.

\subsection{Water footprint of soy products}

The operational water footprints of soy milk and soy burger are very small (Tables 2-3). Both green and grey water footprints are zero. The blue water footprint is 0.9 litre of water for soy milk and 0.1 litre for soy burger. The total operational water footprint is thus no more than the water used as ingredient of the products.

Table 2. The water footprint of 1 litre of soy milk.

\begin{tabular}{lcccc}
\hline & \multicolumn{2}{c}{ Water footprint (litres) } \\
\cline { 2 - 4 } & Green & Blue & Grey & Total \\
\hline Water incorporated into the soy milk & 0 & 0.9 & 0 & 0.9 \\
Water consumed during process & 0 & 0 & 0 & 0 \\
Wastewater discharge & 0 & 0 & 0 & $\mathbf{0 . 9}$ \\
\hline Operational water footprint & $\mathbf{0}$ & $\mathbf{0 . 9}$ & $\mathbf{0}$ & 81.5 \\
\hline Soybean (basemilk) & 182.3 & 0 & 1.9 & 0.4 \\
Cane sugar & 71.1 & 9.9 & 0.4 & 1.3 \\
Maize starch & 0.2 & 0 & 0.1 & 19.9 \\
Vanilla flavour & 1.1 & 0.1 & 0 & 0.5 \\
Cardboard & 15.4 & 0.0 & 4.5 & 8.0 \\
Cap & 0.0 & 0.0 & 0.5 & 0.4 \\
Tray - cardboard & 6.2 & 0.0 & 1.8 & $\mathbf{2 9 6}$ \\
Stretch film (LDPE) & 0.0 & 0.0 & $\mathbf{0 . 4}$ & $\mathbf{2 9 6 . 9}$ \\
\hline Supply-chain water footprint & $\mathbf{2 7 6 . 4}$ & $\mathbf{1 0 . 1}$ & $\mathbf{9 . 6}$ & $\mathbf{9 . 6}$ \\
\hline Total & $\mathbf{2 7 6 . 4}$ & $\mathbf{1 1 . 0}$ & & 0.5 \\
\hline
\end{tabular}


Table 3. The water footprint of $150 \mathrm{~g}$ of soy burger.

\begin{tabular}{|c|c|c|c|c|}
\hline & \multicolumn{4}{|c|}{ Water footprint (litres) } \\
\hline & Green & Blue & Grey & Total \\
\hline Water incorporated into the soy milk & 0 & 0.1 & 0 & 0.1 \\
\hline Water consumed during process & 0 & 0 & 0 & 0 \\
\hline Wastewater discharge & 0 & 0 & 0 & 0 \\
\hline Operational water footprint & 0 & 0.1 & 0 & 0.1 \\
\hline Soybean (basemilk) & 69.1 & 4.8 & 29.5 & 103.4 \\
\hline Maize & 2.6 & 0.8 & 1.1 & 4.5 \\
\hline Soy milk powder & 10.9 & 0.6 & 0.1 & 11.7 \\
\hline Soya paste & 1.7 & 0.1 & 0.0 & 1.8 \\
\hline Onions & 0.3 & 0 & 0.1 & 0.4 \\
\hline Paprika green & 0.2 & 0 & 0.2 & 0.4 \\
\hline Carrots & 0.1 & 0 & 0 & 0.2 \\
\hline Sleeve (cardboard) & 9.2 & 0 & 2.7 & 11.9 \\
\hline Plastic cup & 0.0 & 0 & 3.5 & 3.5 \\
\hline $\begin{array}{l}\text { Cardboard box (contains } 6 \text { burger } \\
\text { packs) }\end{array}$ & 15.4 & 0 & 4.5 & 19.9 \\
\hline Stretch film (LDPE) & 0 & 0 & 0.1 & 0.1 \\
\hline Supply-chain water footprint & 109.5 & 6.4 & 41.8 & 157.8 \\
\hline Total & 109.5 & 6.5 & 41.8 & 157.9 \\
\hline
\end{tabular}

The water footprints of the two soy products are largely determined by the supply chain components. About $62 \%$ of the total water footprint of soy milk refers to the water footprint of soybean cultivation. In the case of soy burger, this is $74 \%$. In the case of soy milk, $90 \%$ of the supply-chain water footprint is from ingredients (mainly soybean and cane sugar) and $10 \%$ is from other components (mainly cardboard). For soy burger, the percentages are $78 \%$ and $22 \%$ respectively.

The results tabulated in Tables 2 and 3 are calculated based on the figures given in Appendices I and II. As an example, we show here the calculation of the water footprint of soybean used in $150 \mathrm{~g}$ of soy burger. The amount of soybean used in the soy burger is $0.025 \mathrm{~kg}$ and is cultivated in Canada and France (50\% each). All soybeans come from non-organic farms. In France, the soybean come partly from rainfed lands and partly from irrigated lands. The Canadian soybean are taken from rainfed fields. The water footprints of soybeans as primary crop from different locations are given in Table 4. The green, blue and grey water footprints of soybean from Canada are 2069, 0 and $1103 \mathrm{~m}^{3} /$ ton, respectively. For rainfed soybean from France this is 2048, 0, and $603 \mathrm{~m}^{3} /$ ton, respectively. For irrigated French soybean, we find values of 1255, 519 and $370 \mathrm{~m}^{3} /$ ton. Based on relative amounts per source, we can calculate that the green, blue and grey water footprints of the resulting soybean mix are 1860, 130 and $795 \mathrm{~m}^{3} /$ ton, respectively. 
Table 4. Summary of the water footprints of soybeans as primary crop (as input to a soy burger).

\begin{tabular}{lccccc}
\hline \multirow{2}{*}{ Farm } & \multicolumn{3}{c}{ Water footprint $\left(\mathrm{m}^{3} /\right.$ ton $)$} & \multicolumn{2}{c}{$\begin{array}{c}\text { Percentage } \\
\text { in mix }\end{array}$} \\
\cline { 2 - 5 } & Green & Blue & Grey & Total & 50 \\
\hline Canada (non-organic, rainfed) & 2069 & 0 & 1103 & 3172 & 25 \\
France (non-organic, rainfed) & 2048 & 0 & 603 & 2651 & 25 \\
France (non-organic, irrigated) & 1255 & 519 & 370 & 2145 & 25 \\
Soybean mix (for soy burger) & 1860 & 130 & 795 & 1860 & \\
\hline
\end{tabular}

About $86 \%$ of the weight of soybean becomes dehulled soybean (DS) and about $74 \%$ of the DS weight becomes base milk. The product fraction for soybean in the product (basemilk) is thus $0.86 \times 0.74=0.64$. In the process from soybean to basemilk, there are also by-products with some value. The value of the basemilk is $94 \%$ of the aggregated value of soybean products. Therefore, $94 \%$ of the water footprint of the soybean is attributed to basemilk. The water footprint of the basemilk as used in the soy milk is calculated by multiplying the water footprint of soybean by the value fraction and amount used and dividing by the product fraction. The green water footprint of the basemilk is thus: $(1860 \times 0.94 \times 0.025) / 0.64=69.1$ litres. The blue water footprint: $(130 \times 0.94 \times 0.025) / 0.64=4.8$ litres. The grey water footprint: $(795 \times 0.94 \times 0.025) / 0.64=29.5$ litres .

The total water footprints of 1 litre of soy milk and $150 \mathrm{~g}$ of soy burger are calculated as 297 and 158 litres respectively. For soy milk, 99.7\% of total water footprint stems from the supply-chain water footprint. For soy burger this is $99.9 \%$. This highlights the importance of detailed supply chain assessments for both products and businesses. Common practice in business water accounting is the focus on the operational water consumption. However, this study shows that compared to the supply-chain water footprint, the operational side is almost negligible. The diagrams in Figure 4 show the colour composition of the water footprints of soy milk and soy burger. $93 \%$ of the total water footprint of the 1 litre of soy milk is from green water resources, $4 \%$ is from blue water resources and $3 \%$ is the grey water footprint component. The colours of the water footprint of $150 \mathrm{~g}$ soy burger are $69 \%$ green, $4 \%$ blue and $27 \%$ the grey.

\section{Soymilk}

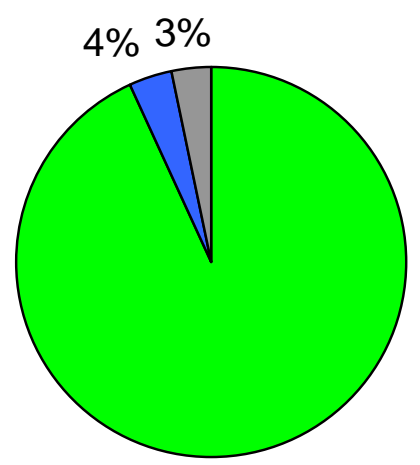

93\%
Soy burgers

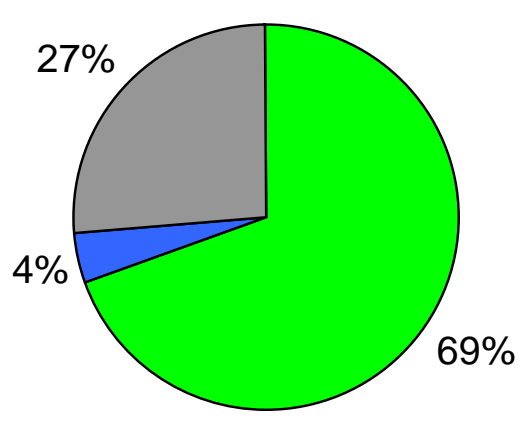

$\square$ Green WF

$\square$ Blue WF

$\square$ Grey WF

Figure 4. The green, blue and grey shares in the total water footprints of 1 litre soy milk and $150 \mathrm{~g}$ soy burger. 


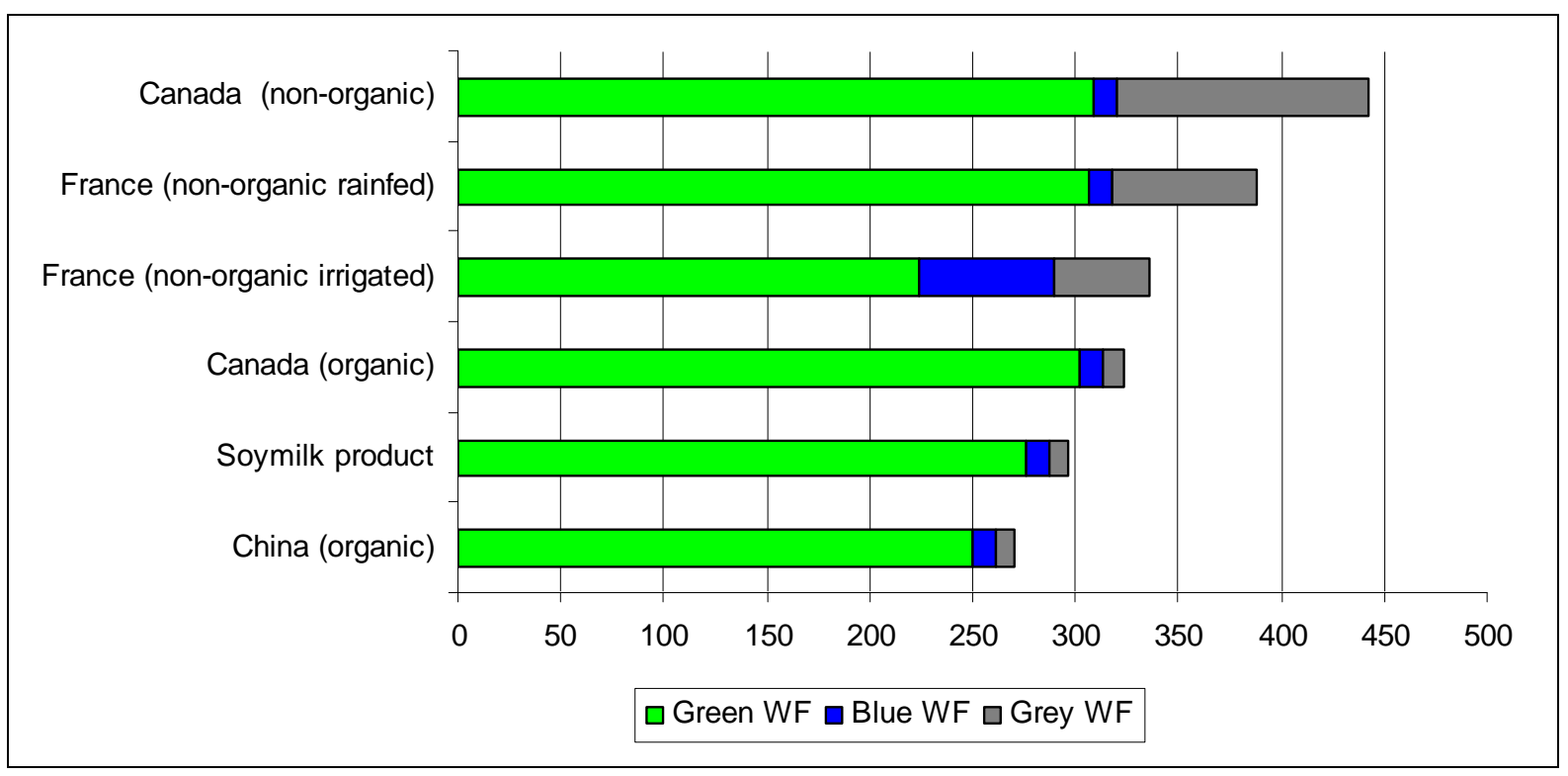

Figure 5. The total water footprint of soy milk with soybean input from different farms (litres).

The water footprints of soy milk and soy burger from the Belgian and Dutch factories are calculated based on the percentages of soybean intake from different farms. Figure 5 shows the change in the total footprint of 1 litre of soy milk according to farm location and type of agricultural practice (organic vs. non-organic and rainfed vs. irrigated). The soybean used as an ingredient in the 'soy milk product' is supplied from both Canadian and Chinese organic farms (50\% each). Figure 5 shows the total water footprint values of the same product when soybeans are fully supplied from either the Canadian organic, Chinese organic, French non-organic rainfed, French non-organic irrigated, or Canadian non-organic farm. If the soybean were only supplied from the Canadian non-organic farm, the water footprint of 1 litre of soy milk would be $49 \%$ larger. If all soybeans were supplied from the Chinese organic farm, then the water footprint of the soy milk product would be $9 \%$ smaller. Shifting from full non-organic (as in the one Canadian farm) to full organic (as in the other Canadian farm) reduces the grey water footprint related to soybean cultivation by $98 \%$.

The case of French farms is a good example of how irrigation can affect the water footprint value. The two French farms are located in the same region with similar climatic conditions. However, the first farm irrigates its field to obtain higher yields and the second farm cultivates soybean only with rainwater. The comparison of the water footprints shows that soybeans from the irrigated farm have a smaller total water footprint (14\%), but the irrigated soybeans have a five times larger blue water footprint and a larger grey water footprint as well. This result is important, as generally competition over blue water resources is larger (i.e. they are scarcer), so that it may well be that from both an economic and environmental point of view the benefit of the reduced blue and grey water footprints in rainfed farming exceeds the cost of the increased green water footprint. Obviously, the analysis presented here is a partial one, focussed on showing green and blue water consumption and pollution; for a complete assessment of rainfed versus irrigated farming one needs to take other relevant factors into account as well, like the costs of both practices and the scarcity of (i.e. the competition over) both the green and blue water resources. 


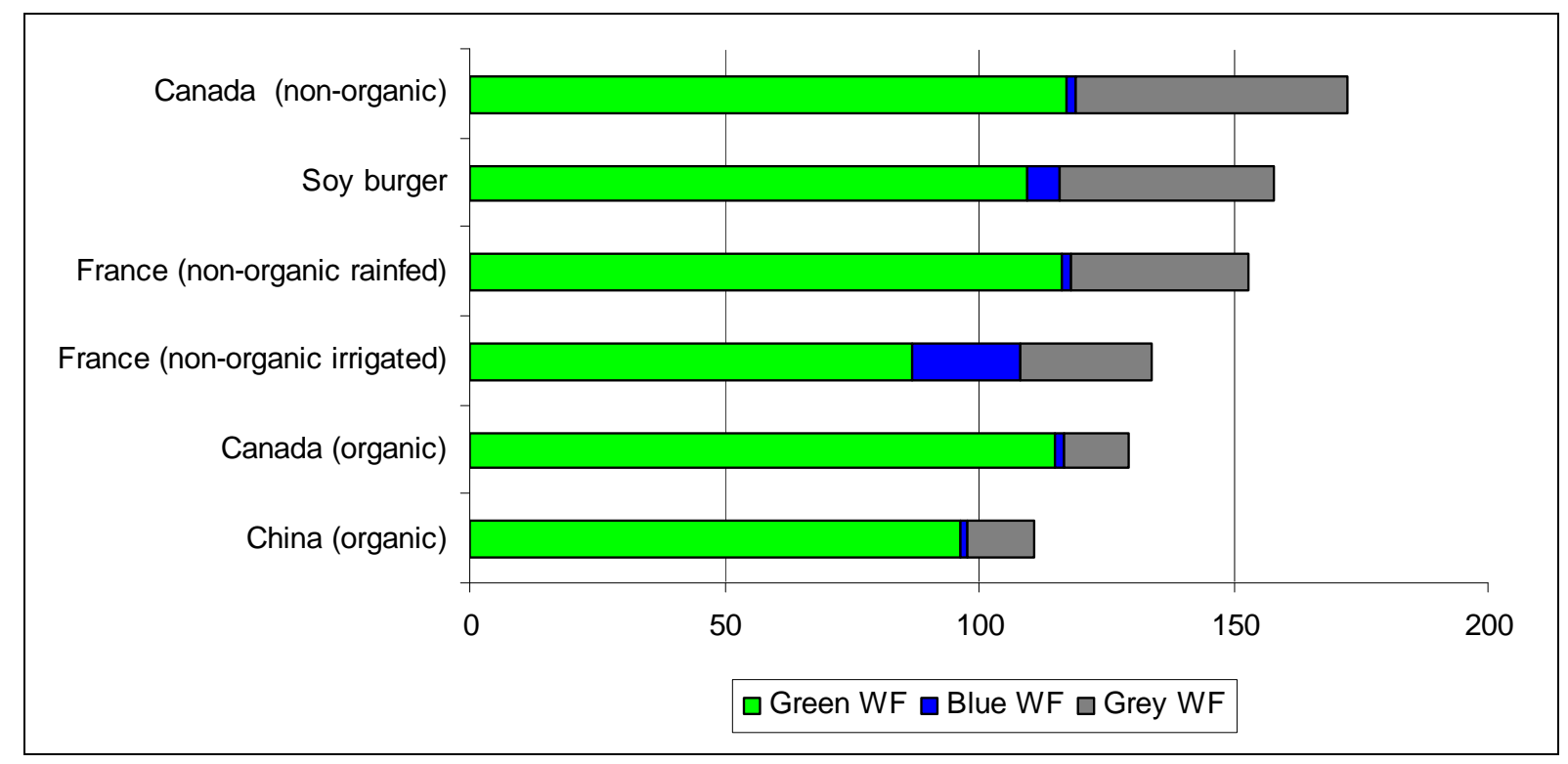

Figure 6. The total water footprint of soy burger with soybean input from different farms (litres).

The soybean in the $150 \mathrm{~g}$ of soy burger is supplied from three different farms: a non-organic Canadian farm (supplying 50\% of the soybean) and two non-organic French farms, a rainfed one and an irrigated one (both supplying 25\%). The total water footprint of this soy burger is 158 litres (Figure 6). If we would source soybean only from the Canadian non-organic farm, the total water footprint of our product would be $9 \%$ larger. However, if we would source soybean from the Chinese organic farm that we studied for the soy milk case, the total water footprint of our soy burger would decrease by $30 \%$.

\subsection{Water footprint of soy products versus equivalent animal products}

The water footprints of cow's milk and beef burger have been studied in detail before by Chapagain and Hoekstra (2004) and recently by Mekonnen and Hoekstra (2010b). In this study we make use of the estimates from the latter study. For the comparison of cow's milk and soy milk, the water footprint of packaging material is added to the water footprint of cow's milk (27.8 litres per 1 litre of milk). Similarly, the water footprint of packaging materials is added to the beef burger for fair comparison with the soy burger (35.5 litres per $150 \mathrm{~g}$ of beef burger).

Figure 7 shows the water footprint of 1 litre of soy milk produced in Belgium in comparison to the water footprint of 1 litre of cow's milk from various locations. The smallest water footprint of cow's milk is 540 litres for the UK and the largest is 1800 litres for Spain, while the world average amounts to 1050 litres.

Figure 8 compares the water footprint of $150 \mathrm{~g}$ of soy burger produced in the Netherlands with the water footprints of beef burgers from different locations. As seen in the figure, soy burger has a smaller water footprint (158 litres) than all the beef burgers from any source. The largest water footprint of beef burger is from Pakistan (3650 litres) and the lowest is from the Netherlands (1000 litres), while the world average is 2350 litres. 


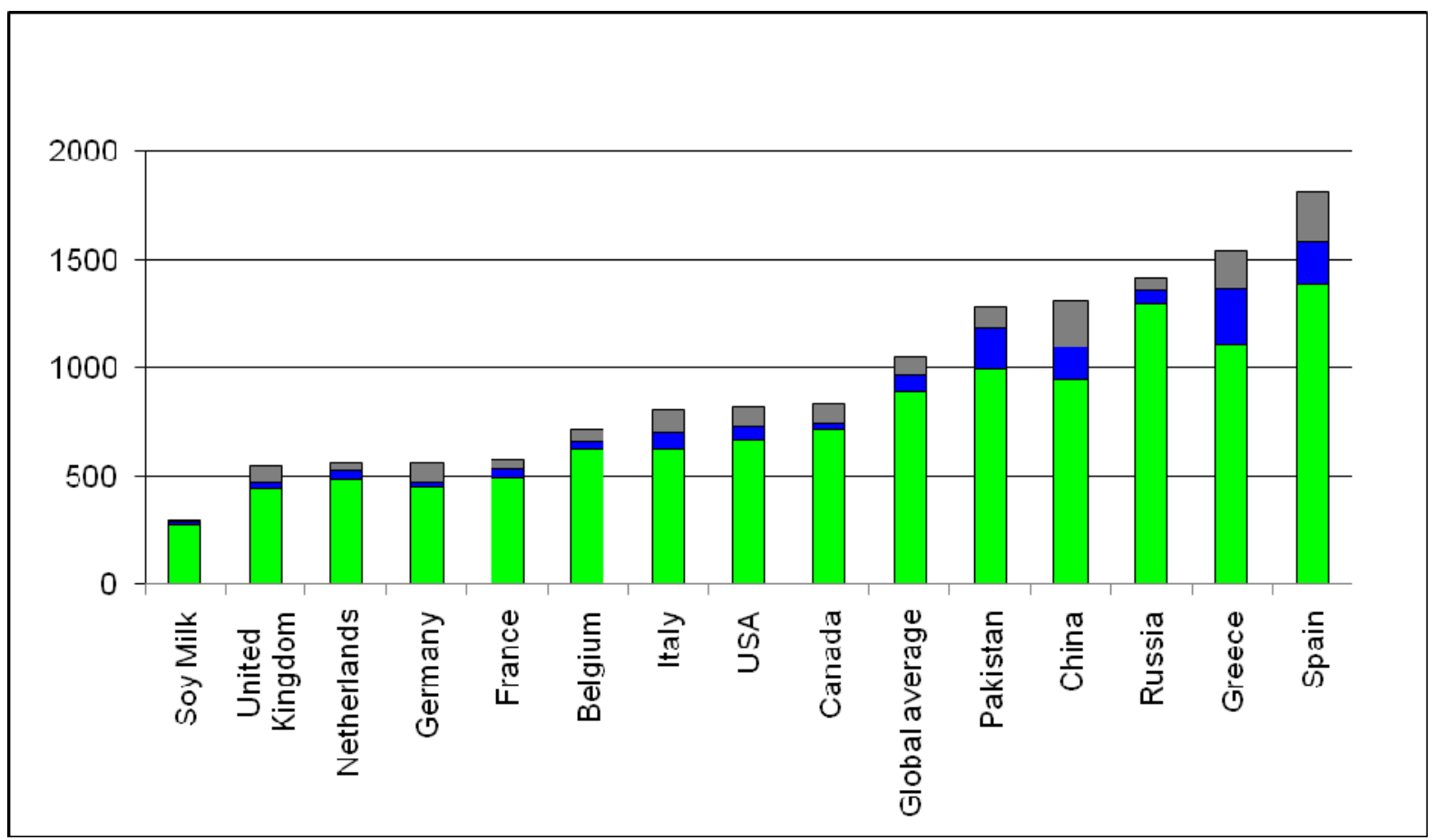

Figure 7. The water footprint of 1 litre of soy milk compared to the water footprint of 1 litre of cow's milk from various locations (in litres).

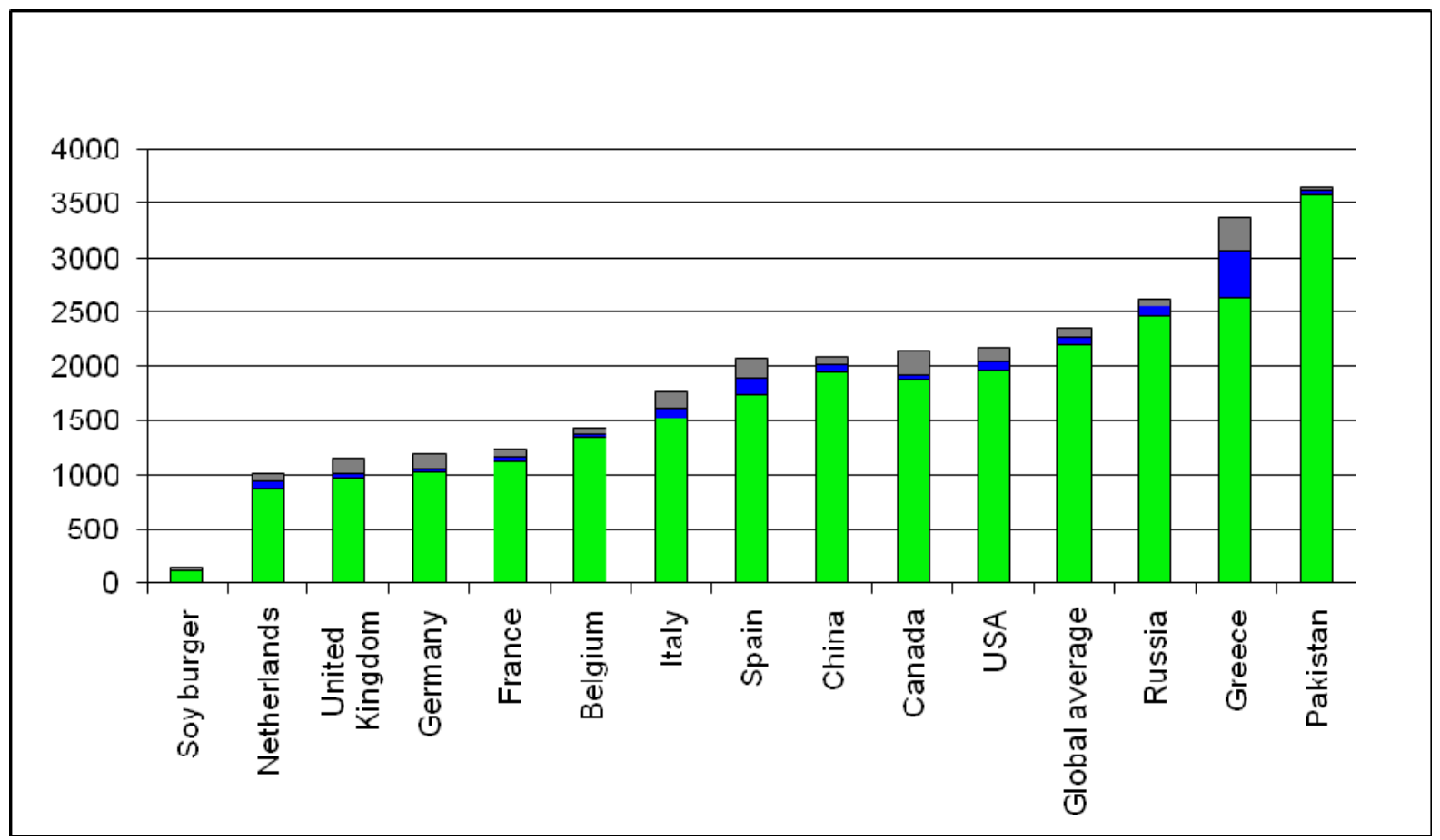

Figure 8. The water footprint of $150 \mathrm{~g}$ of soy burger compared to the water footprint of $150 \mathrm{~g}$ of beef burger from various locations (in litres). 


\section{Conclusion}

This study shows the importance of a detailed supply-chain assessment in water footprint accounting. Food processing industries commonly consider water use in their own operations only. If they have water use reduction targets, those targets are formulated with regard to their own water use. With examples for two soybean products, this study shows that, however, the operational water footprint is almost negligible compared to the supply-chain water footprint. For a food processing company, it is crucial to recognize farmers as key players if the aim is to reduce the overall water consumption and pollution behind final food products. Engaging with farmers and providing positive incentives for the adoption of better agricultural practices are an essential element in a food company’s effort to make its products sustainable.

The results of the study show that the water footprint of a soy product is very sensitive to where the inputs of production are sourced from and under which conditions the inputs are produced. This is most in particular relevant for the agricultural inputs. The water footprints of soy milk and soy burger depend significantly on the locations of the farms producing the soybean and on the agricultural practices at these farms (organic vs. nonorganic and rainfed vs. irrigated). Not only the total water footprint, but also the colour composition (the ratios green, blue, grey) strongly varies as a function of production location and agricultural practice. These results reveal the importance of the spatial dimension of water accounting.

For the limited number of cases that we have considered, we find that non-organic soybean has a larger water footprint (ranging between 2145-3172 $\mathrm{m}^{3} /$ ton) than organic soybean (1520-2024 $\mathrm{m}^{3} /$ ton). Organic agriculture, apart from having a lower evapotranspiration, reduces the grey water component. Shifting towards organic production will reduce the grey water footprint of agricultural production and thus the damage to aquatic life and ecosystems. Another factor that can be influenced is the degree of irrigation. In the case of the two French farms considered in this study, the total water footprint is larger for rainfed soybean, but the blue water footprint of rainfed soybean is zero.

The study shows that soy milk and soy burger have much smaller water footprints than their equivalent animal products. The water footprint of the soy milk product analysed in this study is $28 \%$ of the water footprint of the global average cow milk. The water footprint of the soy burger examined here is $7 \%$ of the water footprint of the average beef burger in the world.

For a more in-depth analysis of the local environmental and social impacts of water footprints of products, one would have to analyse the water footprints in their geographic context, considering for example local water scarcity and pollution and effects on local ecosystems and social conflict. In the current study, this has not been done because the interest was not to study local impacts, but to compare the claims on freshwater resources of soy products versus equivalent animal products and to consider how the type of agricultural practice (organic versus non-organic; rainfed versus irrigated) can influence freshwater claims as well. 
22 / The water footprint of soy milk and soy burger and equivalent animal products

The current study is not based on field measurements of water consumption and leaching of applied chemicals, but based on statistics supplied by the farms and simple models to estimate evapotranspiration and water pollution. The figures presented should therefore be considered as very rough first estimates only. 


\section{References}

Allen, R.G., Pereira, L.S., Raes, D. and Smith, M. (1998) Crop evapotranspiration - Guidelines for computing crop water requirements, FAO Irrigation and Drainage Paper 56, Food and Agriculture Organization, Rome.

Chapagain, A.K. and Hoekstra, A.Y. (2004) Water footprints of nations, Value of Water Research Report Series No. 16, UNESCO-IHE, Delft, the Netherlands. Available online: www.waterfootprint.org/Reports/Report16Vol1.pdf

De Fraiture, C., Wichelns, D., Rockström, J., Kemp-Benedict, E., Eriyagama, N., Gordon, L.J., Hanjra, M.A., Hoogeveen, J., Huber-Lee, A. and Karlberg, L. (2007) Looking ahead to 2050: scenarios of alternative investment approaches, In: Molden, D. (ed.) Water for food, water for life: a comprehensive assessment of water management in agriculture, International Water Management Institute, Colombo, Earthscan, London: pp. 91-145.

EC (2010) Organic farming, Water, European Commission, Brussels. Available online: http://ec.europa.eu/agriculture/organic/environment/water_en

Ercin, A.E., Aldaya, M.M. and Hoekstra, A.Y. (2011) Corporate water footprint accounting and impact assessment: The case of the water footprint of a sugar-containing carbonated beverage, Water Resources Management 25(2): 721-741.

FAO (2009a) CROPWAT 8.0 model, Food and Agriculture Organization, Rome. [www.fao.org/nr/water/infores_databases_cropwat.html]. Accessed on January 2010.

FAO (2009b) CLIMWAT 2.0 database, Food and Agriculture Organization, Rome. [www.fao.org/nr/water/infores_databases_climwat.html]. Accessed on January 2010.

FDA (2006) Code of Federal Regulations. 2006. Title 21, Part 169.175, Washington, D.C.

Galloway, J., Burke, M., Bradford, G. E., Naylor, R., Falcon, W., Chapagain, A.K., Gaskell, J.C., McCullough, E., Mooney, H.A., Oleson, K.L.L., Steinfeld, H., Wassenaar, T., Smil, V. (2007) International trade in meat: The tip of the pork chop, Ambio 36: 622-629.

Hoekstra, A.Y. (ed.) (2003) Virtual water trade: Proceedings of the International Expert Meeting on Virtual Water Trade, Delft, The Netherlands, 12-13 December 2002, Value of Water Research Report Series No.12, UNESCO-IHE, Delft, the Netherlands. Available online: Www.waterfootprint.org/Reports/Report12.pdf.

Hoekstra, A.Y. (2010) The water footprint of animal products, In: D'Silva, J. and Webster, J. (eds.) The meat crisis: Developing more sustainable production and consumption, Earthscan, London, UK, pp. 22-33.

Hoekstra, A.Y. and Chapagain, A.K. (2008) Globalization of water: Sharing the planet’s freshwater resources. Blackwell Publishing. Oxford, UK.

Hoekstra, A.Y., Chapagain, A.K., Aldaya, M.M. and Mekonnen, M.M. (2011) The water footprint assessment manual: Setting the global standard, Earthscan, London, UK.

MacDonald, D.D., Berger, T., Wood, K., Brown, J., Johnsen, T., Haines, M.L., Brydges, K., MacDonald, M.J., Smith, S.L. and Shaw. D.P. (1999) A compendium of environmental quality benchmarks, MacDonald Environmental Sciences, Nanaimo, British Columbia, Canada. 
MDEQ (Ministere de l'Environnement du Quebec) (1996) Chimeres de quality de l'eau de surface au Quebec. Quebec City, Quebec. Available online: www.mef.gouv.qc.ca

Mekonnen, M.M. and Hoekstra, A.Y. (2010a) The green, blue and grey water footprint of crops and derived crop, Value of Water Research Report Series No. 47, UNESCO-IHE, Delft, the Netherlands. Available online: www.waterfootprint.org/Reports/Report47-WaterFootprintCrops-Vol1.pdf.

Mekonnen, M.M. and Hoekstra, A.Y. (2010b) The green, blue and grey water footprint of farm animals and animal products, Value of Water Research Report Series No. 48, UNESCO-IHE, Delft, the Netherlands. Available online: www.waterfootprint.org/Reports/Report-48-WaterFootprint-AnimalProducts-Vol1.pdf.

Monfreda, C., Ramankutty, N. and Foley, J.A. (2008) Farming the planet: 2. Geographic distribution of crop areas, yields, physiological types, and net primary production in the year 2000, Global Biogeochemical Cycles, Vol. 22, GB1022.

NCAT (2004) Organic crop production overview. Fundamentals of sustainable agriculture, National Sustainable Agriculture Information Service, The National Center for Appropriate Technology. Available online: http://attra.ncat.org/attra-pub/PDF/organiccrop.pdf

Peden, D., Tadesse, G., Misra, A.K., Ahmed, F.A., Astatke, A., Ayalneh, W., Herrero, M., Kiwuwa, G., Kumsa, T., Mati, B., Mpairwe, D., Wassenaar, T. and Yimegnuhal, A. (2007) Water and livestock for human development, In: Molden, D. (ed.) Water for food, water for life: a comprehensive assessment of water management in agriculture, International Water Management Institute, Colombo, Earthscan, London: pp. 485-514.

Pegram, G., Orr, S. and Williams, C. (2009) Investigating shared risk in water: Corporate engagement with the public policy process, WWF, Godalming, UK.

Rondinelli, D.A. and Berry, M.A. (2000) Environmental citizenship in multinational corporations: Social responsibility and sustainable development, European Management Journal 18(1): 70-84.

Staton, M., Thelen, K. and Silva, G. (2010) Soybean facts: Checklist for improving soybean yields, Michigan State University Extension, Michigan Soybean Promotion Committee, Feb. 2010. Available online: www.michigansoybean.org/MSPCSite/GrowerResources/FactSheets/ChecklistForImprovingSoybeanYields.pdf.

Steinfeld, H., Gerber, P., Wassenaar, T., Castel, V., Rosales, M., de Haan, C. (2006) Livestock’s long shadow: environmental issues and options, Food and Agriculture Organization, Rome. Available online: ftp://ftp.fao.org/docrep/fao/010/a0701e/A0701E.pdf.

UNESCO (2006) Water, a shared responsibility: The United Nations world water development report 2. UNESCO Publishing, Paris / Berghahn Books, Oxford.

Van der Leeden, F., Troise, F.L. and Todd, D.K. (1990) The Water Encyclopaedia - Second edition, CRC Press, Boca Raton, Florida, USA.

Van Oel, P.R. and Hoekstra, A.Y. (2010) The green and blue water footprint of paper products: methodological considerations and quantification, Value of Water Research Report Series No. 46, UNESCO-IHE, Delft, the Netherlands. Available online: www.waterfootprint.org/Reports/Report46-WaterFootprintPaper. 


\section{Appendix I: List of ingredients and other components of the soy products}

\begin{tabular}{lccc}
\hline litre of soy milk & Amount (gram) & Raw material & Source of raw material \\
\hline Ingredients* & 70 & Soybean & Canada + China (organic) \\
Soybean & 25 & Sugar cane & Cuba \\
Cane sugar & 0.30 & Maize & China \\
Maize starch & 0.15 & Vanilla & USA \\
Vanilla flavour & 1 & Salt & World market \\
Salt & 4 & Natural calcium chalk market \\
Calcium carbonate & & & Germany \\
Other components & 25 & wood & world market \\
Cardboard & 2 & oil & Germany \\
Cap & 10 & wood & world market \\
Tray - cardboard & 1.5 & oil & \\
Stretch film (LDPE) & &
\end{tabular}

*Total weight of ingredients is $0.1 \mathrm{~kg}$. The rest of the weight is water, which is added in the operational phase.

$150 \mathrm{~g}$ of soy burger

Amount (gram)*

Raw material

Source of raw material

Ingredients

\begin{tabular}{|c|c|c|c|}
\hline Soybean & 25 & Soybean & France + Canada (non-organic) \\
\hline Maize & 4 & Maize & Turkey \\
\hline Soy milk powder & 4 & Soybean & USA \\
\hline Soya paste & 4 & Soybean & USA \\
\hline Onions & 4 & Onions & The Netherlands \\
\hline Paprika green & 5 & Peppers green & Spain \\
\hline Carrots & 2 & Carrots & The Netherlands \\
\hline Salt & 2 & Salt & World market \\
\hline \multicolumn{4}{|l|}{ her components } \\
\hline Sleeve (cardboard) & 15 & wood & Germany \\
\hline Plastic cup & 15 & oil & world market \\
\hline $\begin{array}{l}\text { Cardboard box (contains } 6 \\
\text { burger packs) }\end{array}$ & 25 & wood & Germany \\
\hline Stretch film (LDPE) & 0.5 & oil & world market \\
\hline
\end{tabular}

*Total weight of ingredients is $0.05 \mathrm{~kg}$. The rest of the weight is water, which is added in the operational phase. 
Appendix II: Water footprints of raw materials and process water footprints for the ingredients and other components of the soy products

\begin{tabular}{|c|c|c|c|c|c|c|c|c|c|c|}
\hline \multirow{2}{*}{$\begin{array}{l}1 \text { litre of } \\
\text { soy milk }\end{array}$} & \multirow{2}{*}{$\begin{array}{l}\text { Raw } \\
\text { material }\end{array}$} & \multirow{2}{*}{ Source } & \multicolumn{3}{|c|}{$\begin{array}{l}\text { Water footprint of raw } \\
\text { material }\left(\mathrm{m}^{3} / \text { ton }\right)^{\mathrm{a}}\end{array}$} & \multicolumn{3}{|c|}{$\begin{array}{l}\text { Process water footprint } \\
\qquad\left(\mathrm{m}^{3} / \text { ton }\right)^{\mathrm{b}}\end{array}$} & \multicolumn{2}{|c|}{$\begin{array}{l}\text { Fractions for } \\
\text { products used }\end{array}$} \\
\hline & & & Green & Blue & Grey & Green & Blue & Grey & $\begin{array}{l}\text { Product } \\
\text { fraction }\end{array}$ & $\begin{array}{l}\text { Value } \\
\text { fraction }\end{array}$ \\
\hline \multicolumn{11}{|l|}{ Ingredients } \\
\hline Soybean $^{c}$ & Soybean & $\begin{array}{c}\text { Canada + } \\
\text { China } \\
\text { (organic) }\end{array}$ & 1753.5 & 0 & 18.5 & 0 & 0 & 0 & 0.64 & 0.95 \\
\hline Cane sugar & Sugar cane & Cuba & 358 & 50 & 2 & 0 & 0 & 0 & 0.11 & 0.87 \\
\hline Maize starch & Maize & China & 565 & 12 & 335 & 0 & 0 & 0 & 0.75 & 1 \\
\hline Vanilla flavour & Vanilla & USA & 67269 & 7790 & 0 & 0 & 0 & 0 & $9^{d}$ & 1 \\
\hline \multicolumn{11}{|c|}{ Other components } \\
\hline Cardboard & wood & Germany & 616 & 0 & 0 & 0 & 0 & 180 & 1 & 1 \\
\hline Cap & oil & $\begin{array}{l}\text { Sweden } \\
\text { (raw) - } \\
\text { Germany } \\
\text { (process) }\end{array}$ & 0 & 0 & 10 & 0 & 0 & 225 & 1 & 1 \\
\hline $\begin{array}{l}\text { Tray - } \\
\text { cardboard }\end{array}$ & wood & Germany & 616 & 0 & 0 & 0 & 0 & 180 & 1 & 1 \\
\hline $\begin{array}{l}\text { Stretch film } \\
\text { (LDPE) }\end{array}$ & oil & $\begin{array}{l}\text { Sweden } \\
\text { (raw) - } \\
\text { Germany } \\
\text { (process) }\end{array}$ & 0 & 0 & 10 & 0 & 0 & 225 & 1 & 1 \\
\hline
\end{tabular}

${ }^{\text {a }}$ Mekonnen and Hoekstra (2010a); Van Oel and Hoekstra (2010) for wood.

${ }^{\text {b }}$ Van der Leeden et al. (1990)

${ }^{c}$ Data for soybean: own calculations.

${ }^{d}$ FDA (2006) 


\begin{tabular}{|c|c|c|c|c|c|c|c|c|c|c|}
\hline \multirow{2}{*}{$\begin{array}{l}150 \mathrm{~g} \text { of } \\
\text { soy burger }\end{array}$} & \multirow{2}{*}{$\begin{array}{l}\text { Raw } \\
\text { material }\end{array}$} & \multirow{2}{*}{ Source } & \multicolumn{3}{|c|}{$\begin{array}{l}\text { Water footprint of raw } \\
\text { material }\left(\mathrm{m}^{3} / \text { ton }\right)^{\mathrm{a}}\end{array}$} & \multicolumn{3}{|c|}{$\begin{array}{l}\text { Process water footprint } \\
\left(\mathrm{m}^{3} / \text { ton }\right)^{\mathrm{b}}\end{array}$} & \multicolumn{2}{|c|}{$\begin{array}{l}\text { Fractions for } \\
\text { products used }\end{array}$} \\
\hline & & & Green & Blue & Grey & Green & Blue & Grey & $\begin{array}{l}\text { Product } \\
\text { fraction }\end{array}$ & $\begin{array}{l}\text { Value } \\
\text { fraction }\end{array}$ \\
\hline \multicolumn{11}{|l|}{ Ingredients } \\
\hline Soybean $^{c}$ & Soybean & $\begin{array}{c}\text { France + } \\
\text { Canada } \\
\text { (non- } \\
\text { organic) }\end{array}$ & 1860 & 130 & 795 & 0 & 0 & 0 & 0.64 & 0.95 \\
\hline Maize & Maize & Turkey & 646 & 208 & 277 & 0 & 0 & 0 & 1 & 1 \\
\hline $\begin{array}{l}\text { Soy milk } \\
\text { powder }\end{array}$ & Soybean & USA & 1560 & 92 & 10 & 0 & 0 & 0 & 0.57 & 1 \\
\hline Soya paste & Soybean & USA & 1560 & 92 & 10 & 0 & 0 & 0 & 3.75 & 1 \\
\hline Onions & Onions & $\begin{array}{l}\text { Nether- } \\
\text { lands }\end{array}$ & 68 & 5 & 18 & 0 & 0 & 0 & 1 & 1 \\
\hline Paprika green & $\begin{array}{l}\text { Peppers } \\
\text { green }\end{array}$ & Spain & 39 & 3 & 37 & 0 & 0 & 0 & 1 & 1 \\
\hline Carrots & Carrots & $\begin{array}{l}\text { Nether- } \\
\text { lands }\end{array}$ & 57 & 3 & 18 & 0 & 0 & 0 & 1 & 1 \\
\hline \multicolumn{11}{|c|}{ Other components } \\
\hline $\begin{array}{l}\text { Sleeve } \\
\text { (cardboard) }\end{array}$ & wood & Germany & 616 & 0 & 0 & 0 & 0 & 180 & 1 & 1 \\
\hline Plastic cup & oil & $\begin{array}{l}\text { Sweden } \\
\text { (raw) - } \\
\text { Germany } \\
\text { (process) }\end{array}$ & 0 & 0 & 10 & 0 & 0 & 225 & 1 & 1 \\
\hline $\begin{array}{l}\text { Cardboard box } \\
\text { (contains } 6 \\
\text { burger packs) }\end{array}$ & wood & Germany & 616 & 0 & 0 & 0 & 0 & 180 & 1 & 1 \\
\hline $\begin{array}{l}\text { Stretch film } \\
\text { (LDPE) }\end{array}$ & oil & $\begin{array}{l}\text { Sweden } \\
\text { (raw) - } \\
\text { Germany } \\
\text { (process) }\end{array}$ & 0 & 0 & 10 & 0 & 0 & 225 & 1 & 1 \\
\hline
\end{tabular}

${ }^{a}$ Mekonnen and Hoekstra (2010a); Van Oel and Hoekstra (2010) for wood.

${ }^{\text {b }}$ Van der Leeden et al. (1990)

${ }^{c}$ Data for soybean: own calculations. 


\section{Appendix III: Fertilizer and pesticide application and the grey water footprint related to} soybean production in the analysed farms in Canada, China and France

\begin{tabular}{|c|c|c|c|c|c|c|c|}
\hline $\begin{array}{l}\text { Type of } \\
\text { agriculture }\end{array}$ & Chemical & $\begin{array}{c}\text { Active } \\
\text { substance }\end{array}$ & $\begin{array}{l}\text { Application } \\
\text { rate }(\mathrm{kg} / \mathrm{ha})\end{array}$ & $\begin{array}{l}\text { Leaching } \\
\text { rate (\%) }\end{array}$ & $\begin{array}{l}\text { Leaching rate } \\
\text { source }\end{array}$ & $\begin{array}{l}\text { Standard } \\
(\mathrm{mg} / \mathrm{l})\end{array}$ & Standard source \\
\hline \multirow[t]{4}{*}{ Organic } & $\begin{array}{l}\text { Sulphate of } \\
\text { potash }\end{array}$ & sulphate & 25 & 60 & $\begin{array}{c}\text { Eriksen and } \\
\text { Askegaard } \\
(2000)\end{array}$ & 300 & $\begin{array}{l}\text { MDEQ (1996) in } \\
\text { MacDonald et } \\
\text { al. (1999) }\end{array}$ \\
\hline & $\begin{array}{c}\text { Rock } \\
\text { phosphate }\end{array}$ & phosphorus & 11 & 0 & & & \\
\hline & $\begin{array}{l}\text { Organic } \\
\text { compost }\end{array}$ & nitrogen & 1 & 10 & $\begin{array}{l}\text { Hoekstra and } \\
\text { Chapagain } \\
(2008)\end{array}$ & 10 & EPA (2010) \\
\hline & $\begin{array}{l}\text { Potassium } \\
\text { chloride }\end{array}$ & chloride & 20 & 85 & $\begin{array}{l}\text { Stites and } \\
\text { Kraft (2001) }\end{array}$ & 860 & $\begin{array}{l}\text { EPA (2010) } \\
\text { CMC - Criteria } \\
\text { Maximum } \\
\text { Concentration }\end{array}$ \\
\hline \multirow[t]{6}{*}{ Inorganic } & TSP & phosphorus & 24 & 0 & & & \\
\hline & Touchdown & glyphosate & 1 & 0.01 & $\begin{array}{l}\text { Dousset et al. } \\
\quad(2004)\end{array}$ & 0.065 & $\begin{array}{l}\text { MDEQ (1996) in } \\
\text { MacDonald et } \\
\text { al. (1999) }\end{array}$ \\
\hline & Boundary & metolachlor & 2.4 & 1 & Singh (2003) & 0.008 & $\begin{array}{l}\text { MDEQ (1996) in } \\
\text { MacDonald et } \\
\text { al. (1999) }\end{array}$ \\
\hline & Boundary & metribuzin & 2.4 & 0 & $\begin{array}{l}\text { Kjaer et al. } \\
\text { (2005) }\end{array}$ & 0.001 & $\begin{array}{l}\text { MDEQ (1996) in } \\
\text { MacDonald et } \\
\text { al. (1999) }\end{array}$ \\
\hline & $\mathrm{P}_{2} \mathrm{O}_{5}$ & phosphorus & 33 & 0 & & & \\
\hline & Lasso & alachlor & 2 & 2.5 & $\begin{array}{l}\text { Persicani et } \\
\text { al. (1995) }\end{array}$ & 0.048 & $\begin{array}{l}\text { MDEQ (1996) in } \\
\text { MacDonald et } \\
\text { al. (1999) }\end{array}$ \\
\hline
\end{tabular}

Grey water footprint for organic soybean production in Canada

\begin{tabular}{|c|c|c|c|c|c|c|c|c|}
\hline & $\begin{array}{c}\text { Average } \\
\text { application } \\
\text { rate* }\end{array}$ & Area* $^{*}$ & $\begin{array}{c}\text { Total } \\
\text { application }\end{array}$ & $\begin{array}{c}\text { Leachate to } \\
\text { the water } \\
\text { bodies }\end{array}$ & $\begin{array}{c}\text { Ambient } \\
\text { water quality } \\
\text { standard }\end{array}$ & $\begin{array}{c}\text { Volume of } \\
\text { dilution } \\
\text { water } \\
\text { required } \\
\end{array}$ & Production* & $\begin{array}{c}\text { Grey } \\
\text { water } \\
\text { footprin }\end{array}$ \\
\hline & $\mathrm{kg} / \mathrm{ha}$ & ha & ton/year & ton/year & $\mathrm{mg} / \mathrm{l}$ & $10^{6} \mathrm{~m}^{3} /$ year & ton/yr & $\mathrm{m}^{3} /$ ton \\
\hline Sulphate of potash & 25 & 140 & 4 & 2 & 300 & 0.007 & 350 & 20 \\
\hline Rock phosphate $\left(\mathrm{P}_{2} \mathrm{O}_{5}\right)$ & 11 & 140 & 2 & 0 & & 0 & 350 & 0 \\
\hline $\mathrm{N}$ fertilizer bacteria ${ }^{\star \star \star}$ & 200 & 140 & 28 & & & & & \\
\hline
\end{tabular}

* Data from farms.

** Source: MDEQ (1996) in MacDonald et al. (1999).

*** $\mathrm{N}$ fertilization through symbiotic and endophytic bacteria. 
Grey water footprint for non-organic soybean production in Canada

\begin{tabular}{|c|c|c|c|c|c|c|c|c|}
\hline & $\begin{array}{l}\text { Average } \\
\text { application } \\
\text { rate* }\end{array}$ & Area* $^{*}$ & $\begin{array}{c}\text { Total } \\
\text { application }\end{array}$ & $\begin{array}{l}\text { Leachate to } \\
\text { the water } \\
\text { bodies }\end{array}$ & $\begin{array}{c}\text { Ambient } \\
\text { water quality } \\
\text { standard** }\end{array}$ & $\begin{array}{l}\text { Volume of } \\
\text { dilution } \\
\text { water } \\
\text { required }\end{array}$ & Production* & $\begin{array}{c}\text { Grey } \\
\text { water } \\
\text { footprint }\end{array}$ \\
\hline & $\mathrm{kg} / \mathrm{ha}$ & ha & ton/year & ton/year & $\mathrm{mg} / \mathrm{l}$ & $10^{6} \mathrm{~m}^{3} /$ year & ton/yr & $\mathrm{m}^{3} /$ ton \\
\hline Potassium chloride & 20 & 1000 & 20 & 17 & 860 & 0.02 & 2500 & 8 \\
\hline TSP $\left(\mathrm{P}_{2} \mathrm{O}_{5}\right)$ & 24 & 1000 & 24 & 0 & & 0 & 2500 & 0 \\
\hline Touchdown & 1 & 1000 & 1 & 0 & 0.065 & 0.001 & 2500 & 1 \\
\hline Boundary & 2 & 1000 & 2 & 0 & 0.008 & 2.758 & 2500 & 1103 \\
\hline
\end{tabular}

* Data from farms.

** Sources: EPA (2010) for chloride; MDEQ (1996) in MacDonald et al. (1999) for glyphosate and metolachlor.

Grey water footprint for organic soybean production in China

\begin{tabular}{|c|c|c|c|c|c|c|c|c|}
\hline & $\begin{array}{l}\text { Average } \\
\text { application } \\
\text { rate* }^{*}\end{array}$ & Area* $^{*}$ & $\begin{array}{c}\text { Total } \\
\text { application }\end{array}$ & $\begin{array}{c}\text { Leachate to } \\
\text { the water } \\
\text { bodies }\end{array}$ & $\begin{array}{c}\text { Ambient } \\
\text { water quality } \\
\text { standard** }\end{array}$ & $\begin{array}{l}\text { Volume of } \\
\text { dilution } \\
\text { water } \\
\text { required }\end{array}$ & Production* & $\begin{array}{c}\text { Grey } \\
\text { water } \\
\text { footprint }\end{array}$ \\
\hline & $\mathrm{kg} / \mathrm{ha}$ & ha & ton/year & ton/year & $\mathrm{mg} / \mathrm{l}$ & $10^{6} \mathrm{~m}^{3} /$ year & ton/yr & $\mathrm{m}^{3} /$ ton \\
\hline Sulphate of potash & 25 & 2725 & 68 & 41 & 300 & 0 & 7902 & 17 \\
\hline Organic compost $(\mathrm{N})$ & 1 & 2725 & 3 & 0 & 10 & 0 & 7902 & 4 \\
\hline $\mathrm{P}_{2} \mathrm{O}_{5}$ & 33 & 2725 & 90 & 0 & & 0 & 7902 & 0 \\
\hline
\end{tabular}

* Data from farms.

** Sources: MDEQ (1996) in MacDonald et al. (1999) for sulphate; EPA (2010) for nitrogen.

Grey water footprint for non-organic rainfed soybean production in France

\begin{tabular}{|c|c|c|c|c|c|c|c|c|}
\hline & $\begin{array}{c}\text { Average } \\
\text { application } \\
\text { rate* }^{*}\end{array}$ & Area* & $\begin{array}{c}\text { Total } \\
\text { application }\end{array}$ & $\begin{array}{c}\text { Leachate to } \\
\text { the water } \\
\text { bodies }\end{array}$ & $\begin{array}{c}\text { Ambient } \\
\text { water quality } \\
\text { standard }^{* *}\end{array}$ & $\begin{array}{l}\text { Volume of } \\
\text { dilution } \\
\text { water } \\
\text { required }\end{array}$ & Production* & $\begin{array}{c}\text { Grey } \\
\text { water } \\
\text { footprint }\end{array}$ \\
\hline & $\mathrm{kg} / \mathrm{ha}$ & ha & ton/year & ton/year & $\mathrm{mg} / \mathrm{l}$ & $10^{6} \mathrm{~m}^{3} /$ year & ton/yr & $\mathrm{m}^{3} /$ ton \\
\hline $\mathrm{TSP}\left(\mathrm{P}_{2} \mathrm{O}_{5}\right)$ & 40 & 35 & 1 & 0 & & 0 & 67 & 0 \\
\hline Potassium chloride & 20 & 35 & 1 & 0.6 & 860 & 0 & 67 & 10 \\
\hline Lasso (alachlor) & 2 & 35 & 0.1 & 0.002 & 0.048 & 0 & 67 & 603 \\
\hline
\end{tabular}

* Data from farms.

** Data sources: EPA (2010) for chloride; MDEQ (1996) in MacDonald et al. (1999) for alachlor.

Grey water footprint for non-organic irrigated soybean production in France

\begin{tabular}{|c|c|c|c|c|c|c|c|c|}
\hline & $\begin{array}{c}\text { Average } \\
\text { application } \\
\text { rate* }^{*}\end{array}$ & Area* $^{*}$ & $\begin{array}{c}\text { Total } \\
\text { application }\end{array}$ & $\begin{array}{c}\text { Leachate to } \\
\text { the water } \\
\text { bodies }\end{array}$ & $\begin{array}{c}\text { Ambient } \\
\text { water quality } \\
\text { standard }^{\star *}\end{array}$ & $\begin{array}{l}\text { Volume of } \\
\text { dilution } \\
\text { water } \\
\text { required }\end{array}$ & Production* & $\begin{array}{c}\text { Grey } \\
\text { water } \\
\text { footprint }\end{array}$ \\
\hline & $\mathrm{kg} / \mathrm{ha}$ & ha & ton/year & ton/year & $\mathrm{mg} / \mathrm{l}$ & $10^{6} \mathrm{~m}^{3} /$ year & ton/yr & $\mathrm{m}^{3} /$ ton \\
\hline $\mathrm{TSP}\left(\mathrm{P}_{2} \mathrm{O}_{5}\right)$ & 40 & 35 & 1 & 0 & & 0 & 109 & 0 \\
\hline Potassium chloride & 20 & 35 & 1 & 0.6 & 860 & 0 & 109 & 6 \\
\hline Lasso (alachlor) & 2 & 35 & 0.1 & 0.002 & 0.048 & 0 & 109 & 370 \\
\hline
\end{tabular}

* Data from farms.

** Data sources: EPA (2010) for chloride; MDEQ (1996) in MacDonald et al. (1999) for alachlor. 



\section{Value of Water Research Report Series}

Editorial board:

Arjen Y. Hoekstra - University of Twente, a.y.hoekstra@utwente.nl

Hubert H.G. Savenije - Delft University of Technology, h.h.g.savenije@tudelft.nl

Pieter van der Zaag - UNESCO-IHE Institute for Water Education, p.vanderzaag@unesco-ihe.org

1. Exploring methods to assess the value of water: A case study on the Zambezi basin.

A.K. Chapagain - February 2000

2. Water value flows: A case study on the Zambezi basin.

A.Y. Hoekstra, H.H.G. Savenije and A.K. Chapagain - March 2000

3. The water value-flow concept.

I.M. Seyam and A.Y. Hoekstra - December 2000

4. The value of irrigation water in Nyanyadzi smallholder irrigation scheme, Zimbabwe. G.T. Pazvakawambwa and P. van der Zaag - January 2001

5. The economic valuation of water: Principles and methods J.I. Agudelo - August 2001

6. The economic valuation of water for agriculture: A simple method applied to the eight Zambezi basin countries J.I. Agudelo and A.Y. Hoekstra - August 2001

7. The value of freshwater wetlands in the Zambezi basin I.M. Seyam, A.Y. Hoekstra, G.S. Ngabirano and H.H.G. Savenije - August 2001

8. 'Demand management' and 'Water as an economic good': Paradigms with pitfalls H.H.G. Savenije and P. van der Zaag - October 2001

9. Why water is not an ordinary economic good H.H.G. Savenije - October 2001

10. Calculation methods to assess the value of upstream water flows and storage as a function of downstream benefits I.M. Seyam, A.Y. Hoekstra and H.H.G. Savenije - October 2001

11. Virtual water trade: A quantification of virtual water flows between nations in relation to international crop trade A.Y. Hoekstra and P.Q. Hung - September 2002

12. Virtual water trade: Proceedings of the international expert meeting on virtual water trade A.Y. Hoekstra (ed.) - February 2003

13. Virtual water flows between nations in relation to trade in livestock and livestock products A.K. Chapagain and A.Y. Hoekstra - July 2003

14. The water needed to have the Dutch drink coffee A.K. Chapagain and A.Y. Hoekstra - August 2003

15. The water needed to have the Dutch drink tea A.K. Chapagain and A.Y. Hoekstra - August 2003

16. Water footprints of nations, Volume 1: Main Report, Volume 2: Appendices A.K. Chapagain and A.Y. Hoekstra - November 2004

17. Saving water through global trade A.K. Chapagain, A.Y. Hoekstra and H.H.G. Savenije - September 2005

18. The water footprint of cotton consumption A.K. Chapagain, A.Y. Hoekstra, H.H.G. Savenije and R. Gautam - September 2005

19. Water as an economic good: the value of pricing and the failure of markets P. van der Zaag and H.H.G. Savenije - July 2006

20. The global dimension of water governance: Nine reasons for global arrangements in order to cope with local water problems A.Y. Hoekstra - July 2006

21. The water footprints of Morocco and the Netherlands A.Y. Hoekstra and A.K. Chapagain - July 2006

22. Water's vulnerable value in Africa P. van der Zaag - July 2006

23. Human appropriation of natural capital: Comparing ecological footprint and water footprint analysis A.Y. Hoekstra - July 2007

24. A river basin as a common-pool resource: A case study for the Jaguaribe basin in Brazil P.R. van Oel, M.S. Krol and A.Y. Hoekstra - July 2007

25. Strategic importance of green water in international crop trade M.M. Aldaya, A.Y. Hoekstra and J.A. Allan - March 2008 
26. Global water governance: Conceptual design of global institutional arrangements

M.P. Verkerk, A.Y. Hoekstra and P.W. Gerbens-Leenes - March 2008

27. Business water footprint accounting: A tool to assess how production of goods and services impact on freshwater resources worldwide

P.W. Gerbens-Leenes and A.Y. Hoekstra - March 2008

28. Water neutral: reducing and offsetting the impacts of water footprints

A.Y. Hoekstra - March 2008

29. Water footprint of bio-energy and other primary energy carriers

P.W. Gerbens-Leenes, A.Y. Hoekstra and Th.H. van der Meer - March 2008

30. Food consumption patterns and their effect on water requirement in China

J. Liu and H.H.G. Savenije - March 2008

31. Going against the flow: A critical analysis of virtual water trade in the context of India's National River Linking Programme

S. Verma, D.A. Kampman, P. van der Zaag and A.Y. Hoekstra - March 2008

32. The water footprint of India

D.A. Kampman, A.Y. Hoekstra and M.S. Krol - May 2008

33. The external water footprint of the Netherlands: Quantification and impact assessment

P.R. van Oel, M.M. Mekonnen and A.Y. Hoekstra - May 2008

34. The water footprint of bio-energy: Global water use for bio-ethanol, bio-diesel, heat and electricity

P.W. Gerbens-Leenes, A.Y. Hoekstra and Th.H. van der Meer - August 2008

35. Water footprint analysis for the Guadiana river basin

M.M. Aldaya and M.R. Llamas - November 2008

36. The water needed to have Italians eat pasta and pizza

M.M. Aldaya and A.Y. Hoekstra - May 2009

37. The water footprint of Indonesian provinces related to the consumption of crop products

F. Bulsink, A.Y. Hoekstra and M.J. Booij - May 2009

38. The water footprint of sweeteners and bio-ethanol from sugar cane, sugar beet and maize P.W. Gerbens-Leenes and A.Y. Hoekstra - November 2009

39. A pilot in corporate water footprint accounting and impact assessment: The water footprint of a sugar-containing carbonated beverage

A.E. Ercin, M.M. Aldaya and A.Y. Hoekstra - November 2009

40. The blue, green and grey water footprint of rice from both a production and consumption perspective A.K. Chapagain and A.Y. Hoekstra - March 2010

41. Water footprint of cotton, wheat and rice production in Central Asia M.M. Aldaya, G. Muñoz and A.Y. Hoekstra - March 2010

42. A global and high-resolution assessment of the green, blue and grey water footprint of wheat M.M. Mekonnen and A.Y. Hoekstra - April 2010

43. Biofuel scenarios in a water perspective: The global blue and green water footprint of road transport in 2030 A.R. van Lienden, P.W. Gerbens-Leenes, A.Y. Hoekstra and Th.H. van der Meer - April 2010

44. Burning water: The water footprint of biofuel-based transport P.W. Gerbens-Leenes and A.Y. Hoekstra - June 2010

45. Mitigating the water footprint of export cut flowers from the Lake Naivasha Basin, Kenya M.M. Mekonnen and A.Y. Hoekstra - June 2010

46. The green and blue water footprint of paper products: methodological considerations and quantification P.R. van Oel and A.Y. Hoekstra - July 2010

47. The green, blue and grey water footprint of crops and derived crop products M.M. Mekonnen and A.Y. Hoekstra - December 2010

48. The green, blue and grey water footprint of animals and derived animal products M.M. Mekonnen and A.Y. Hoekstra - December 2010

49. The water footprint of soy milk and soy burger and equivalent animal products A.E. Ercin, M.M. Aldaya and A.Y. Hoekstra - February 2011

Reports can be downloaded from:

www.waterfootprint.org

www.unesco-ihe.org/value-of-water-research-report-series 

UNESCO-IHE

P.O. Box 3015

2601 DA Delft

The Netherlands

Website www.unesco-ihe.org

Phone +31152151715

University of Twente

Delft University of Technology
UNESCO-IHE

Institute for Water Education
UNIVERSITY OF TWENTE.

TUDelft

Delft University of Technology 